Counsellia: Jurnal Bimbingan dan Konseling

Volume 11 (1) 17 - 30 Mei 2021

ISSN: 2088-3072 (Print) / 2477-5886 (Online)

DOI: 10.25273/counsellia.v11i18585

Available online at: http://e-journal.unipma.ac.id/index.php/JBK

\title{
Addiction Counselor Profession: Perception of Family Support for Recovering from Drug Abuse Addiction
}

\author{
Agus Supriyanto ${ }^{1} \bowtie$, Nurlita Hendiani $^{2}$, Sri Hartini ${ }^{4}$, Farhana Sabri ${ }^{5}$ \\ ${ }^{1}$ Fakultas Keguruan dan Ilmu Pendidikan, Universitas Ahmad Dahlan, Yogyakarta \\ email: $₫$ agus.supriyanto@bk.uad.ac.id \\ ${ }^{2}$ Balai Besar Rehabilitasi Narkoba, Badan Narkotika Nasional, Bogor \\ email: nurlita.hendiani@bnn.go.id \\ ${ }^{3}$ Fakultas Keguruan dan Ilmu Pendidikan, Universitas Ahmad Dahlan, Yogyakarta \\ email: sri.hartini@bk.uad.ac.id \\ ${ }^{4}$ Faculty of Leadership and Management, Universiti Sains Islam Malaysia, Bandar \\ Baru \\ email: farhanasabri@usim.edu.my
}

\begin{abstract}
The family is the smallest unit of society that affects the lives of drug users undergoing rehabilitation programs. Family can be a source of social support for substance users in solving problems through perception. The perception of family support is a source of social support to foster confidence in drug rehabilitation programs. This study aims to determine the level of family support for substance users undergoing drug rehabilitation programs and recommendations for individual, group, and family counselling services. This study used a descriptive research type with the subject $\mathrm{N}=$ 217. The research subjects consisted of male and female genders; the data analysis used quantitative descriptive analysis. The results showed that the category of substance users' perceptions of family support had a low level. The types of users at a deficient level were $2.30 \%$, the low level was $57.14 \%$, the high level was $33.18 \%$, and the very high level was $7.37 \%$. These findings prove that the family's influence is still very minimal for users to recover during rehabilitation. The contribution of family perceptions supports beliefs about recovering from drug addiction. The addiction counsellor profession from guidance and counselling graduates needs to implement family counselling services in collaboration with families in developing perceptions of drug addicts. Recommendations from this study's results are the implementation of family counselling services and support from families in concrete, emotional, informational, and reward.
\end{abstract}

Keywords: Addiction Counselor, Preception of Family Support

Received ; Accepted ; Published

Citation: Supriyanto, Hendiani, Hartini, Sabri (2021). Addiction Counselor Profession: Perception of Family Support for Recovering from Drug Abuse Addiction. Counsellia: Jurnal Bimbingan dan Konseling, 11(1), 17 - 30. Doi.org/10.25273/counsellia.v11i18585 


\section{(cc) BY-NG-SA}

Copyright @2021 Counsellia: Bimbingan dan Konseling

Published by Universitas PGRI Madiun. This work is licensed under the Creative Commons Attribution-NonCommercialShareAlike 4.0 International License

\section{INTRODUCTION}

Legal problems related to drugs do not only occur in Indonesia but also in other countries. This problem arises because of drug manufacturing, drug trafficking, drug use, drug abuse, face-to-face and online drug transactions. The manufacture, distribution, use, abuse and sale of drugs or illegal drugs are criminal acts and become legal issues (Hughes \& Stevens, 2010).

Drug use poses a problem for individuals because drug use peaks in adults from 18 years of age to 26 years of age (Stone et al., 2012). Individuals using drugs are associated with poor mental health such as severe psychological distress, depressed thoughts, lively emotions, and suicidal behaviour (Ali et al., 2015; Claro et al., 2015; Merrick et al., 2017). Uncontrolled emotions lead to maladaptive behaviour towards oneself or others. Therefore, a negative stigma arises from the surrounding community or family. Uncontrolled emotions in drug users occur in the form of death, disgust, fear, and sadness (Fernández-Serrano et al., 2010).

Apart from having an impact on mental health, the impact of drugs on physical health also appears. The effect of drugs indirectly causes disease in the human body. This condition is self-defeating or spreads to partners or the opposite sex. This condition is following the research results that the practice of mixing several drugs or alcohol in sequence or at the same time increases the risk of HIV transmission and death from accidental overdoses (Roth et al., 2015). Apart from infectious diseases, they can also cause or worsen existing conditions, such as cancer (Vakonaki et al., 2019).

Then, drugs also have a social impact on their users. Families become distrustful of individuals with substance use disorder (SUD). Society gives a negative stamp to individuals with SUD. Peers or other people become disrespectful to individuals with SUD. Individuals who are considered SUD sufferers because of anxious processes of family interaction and irregular behaviour. Irregular behaviour leads to academic failure and peer rejection, increasing the risk of depression and involvement in deviant, problematic peer groups during childhood and early adolescence, thereby engaging in habitual delinquent behaviour. Another factor is chronic stress in prepubertal children through adolescents drinking alcohol and drug dependence until early adulthood (Enoch, 2011).

Drug users are considered to have a negative stigma in society/family and are considered problematic people. Drug problems and people using them are considered problematic users and hinder alternative understanding of shifting drug use's nature (Lancaster et al., 2015). People who have problems as drug users have a cause for using drugs. Every individual has different or sometimes different reasons for drug use (Gossop, 2013).

Every country in the world has a drug prevention strategy. Indonesia has the policy to reduce drug abuse, restriction, and distribution of drugs through prevention programs. Indonesia has a Narcotics Eradication, and Abuse Prevention and Abuse Program that involves all social elements with the National Narcotics Agency in each region through the media (Sari, 2017; Wulandari, 2016) is a graduate of guidance and counselling. Drug abuse intervention in Indonesia is homework. The need for intervention for SUD individuals through counselling or prevention services through guidance services. An evidence-based drug prevention program for adolescents in school, family, 
and community drug abuse (Griffin \& Botvin, 2010) is implemented through guidance and counselling programs.

For SUD sufferers, Indonesia also has a Drug Rehabilitation Program to recover from drug dependence (Kencana, 2016). Rehabilitation programs support individuals to recover from drug addiction. Professional addiction counsellors assist with rehabilitation programs. Addiction counsellors in Indonesia are under the authority of graduates from guidance and counselling graduates, psychology graduates, and public health graduates to implement counselling services. All addiction counsellors have the competence to provide counselling services. The two strategies in Indonesia with prevention and rehabilitation support the National Narcotics Agency's policy that drugs have reached a global dimension and require a control strategy. Rehabilitation programs as drug treatment that are integrated with normative and non-discriminatory communities (Cullen \& Jonson, 2011; Gideon, 2010).

The fact is that more women than men relapse during the rehabilitation period with reasons of living alone and not having sex with men, while women are using drugs again because of previous medical history, unstable housing conditions, childlessness, and selling sex (Maehira et al., 2013). Low brain dopamine function in abusers is associated with a higher likelihood of relapse during and post-rehabilitation. Addicts who have social and psychological problems tend to relapse after undergoing drug rehabilitation (Petrova et al., 2015).

Family factors also have a significant influence on individuals with SUD to recover or relapse from substance abuse. Individual psychology also influences the success of the rehabilitation program. The conclusion is that individual perceptions of the family are predictors of the success of drug rehabilitation programs. Family plays a role so that family members can recover from drug addiction; Namely, parents act as role models or good role models, parents as educators in preventing drug abuse, parents as mentors, and families as community partners in preventing drug abuse.

This study aims to determine the perceived level of family support in individuals with SUD and its relevance for appropriate coping strategies. This study focuses on two aspects of perception: cognition and affection, with four forms of family support: emotional support, appreciation support, information support, and concrete support with validity and reliability on the perceived scale of family support (Supriyanto \& Hendiani, 2018). This study's findings can formulate policies on implementing counselling services as an intervention to prevent relapse by addiction counsellors.

\section{RESEARCH METHODS}

\section{Research Design}

This research uses a descriptive quantitative method. The purpose of this study was to determine the perceived level of family support in individuals with SUD.

\section{Data Source}

Research subjects are drug users or addicts who participate in the drug rehabilitation program, Indonesia. The research subjects were 217 with male and female sex. The male research subjects had six home rehabilitation programs: Re-entry, House of Chance, Faith, Care, and Hope. The female research subjects had only one house program, the House of Light. Details of research subjects can be seen in table 1.

Table 1. Research Subjects at the Lido Drug Rehabilitation Center, Indonesia

\begin{tabular}{|c|c|c|c|}
\hline Number & Rehabilitation House & Total & Gender \\
\hline 1. & House of Light & 16 & Female \\
\hline 2. & Re-Entry & 34 & Man \\
\hline
\end{tabular}




\begin{tabular}{|c|c|c|}
\hline 3. & House of Chance & 30 \\
\hline 4. & Faith & 44 \\
\hline 5. & Care & 35 \\
\hline 6. & Hope & 58 \\
\hline \multicolumn{2}{|c|}{ Total } & 217 \\
\hline
\end{tabular}

\section{Data Collection Technique}

This study was measured using two aspects of perception, namely cognition and affection. This study also uses four forms of family support to recover from SUD: emotional support, appreciation support, information support, and trusted support. The measuring instrument uses a scale of perceived family support to improve from validated and tested SUD. The family support perception scale was published with 46 valid statement items with the item-total correlation coefficient value of 0.148 , and the reliability coefficient value of 0.861 or the high-reliability category (Supriyanto \& Hendiani, 2018).

Table 2. Perception Blueprint of Family Support Scale

\begin{tabular}{|c|c|c|}
\hline Variable & Aspect of Perception & Form of Family Support \\
\hline Perceptions & & Kognitif (Pikiran untuk \\
of Family & Pemulihan) & Concrete Support \\
\cline { 3 - 3 } Support for & & Emotional Support \\
\cline { 3 - 3 } Recovering \\
from SUD & & Information Support \\
\cline { 3 - 3 } & Afektif (Feelings to & Award Support \\
\cline { 3 - 3 } & Recovery) & Concrete Support \\
\cline { 3 - 3 } & & Emotional Support \\
\cline { 3 - 3 } & & Information Support \\
\hline
\end{tabular}

\section{Data Analysis Technique}

This study uses a descriptive analysis to determine the level of perceptions about family support. Details of the instrument grid can be seen in table 2 . The study results provide recommendations for counselling services for developing individual perceptions with SUD about family support.

\section{RESULTS AND DISCUSSION}

\section{Result}

\section{Profile of Drug Users in the Drug Rehabilitation Program, Lido, Indonesia}

The research subjects were 217 addicts with saturated sampling, or the entire population in 2018 was used entirely at the Lido Drug Rehabilitation Center, Bogor, Indonesia. From the data available in the research method, most drug users are men, and a small proportion is women. It is known that the average female drug users are $7.27 \%$, and the majority are men, with an average of $92.63 \%$. This data concludes that men are more likely than women to be caught in cases or drug addiction.

Table 3. Percentage of Drug Users by Gender at the Lido Drug Rehabilitation Center, Indonesia

\begin{tabular}{|c|c|c|c|}
\hline Number & Gender & Total & Percentage (\%) \\
\hline 1. & Woman & 16 & $7,27 \%$ \\
\hline 2. & Man & 201 & $92,63 \%$ \\
\hline \multicolumn{2}{|c|}{ Total } & 217 & $100 \%$ \\
\hline
\end{tabular}




\section{Findings Perceptions of Family Support for Recovering from SUD}

These findings found surprising facts about the average percentage of individuals with SUD perceptions of family support for recovery from substance disorders during rehabilitation. Evaluating the perception of family support for individuals with SUD in Indonesia at a low level. $60.37 \%$ of individuals with SUD felt that individual family support was small, and $2.30 \%$ were lacking. Meanwhile, $29.95 \%$ of SUD sufferers view that their family supports personal recovery, and only $7.37 \%$ of SUD sufferers view that their family supports the drug rehabilitation program. The reality is that SUD requires family support, and there is a perception that the community accepts this. Detailed data can be seen in figure 1 .

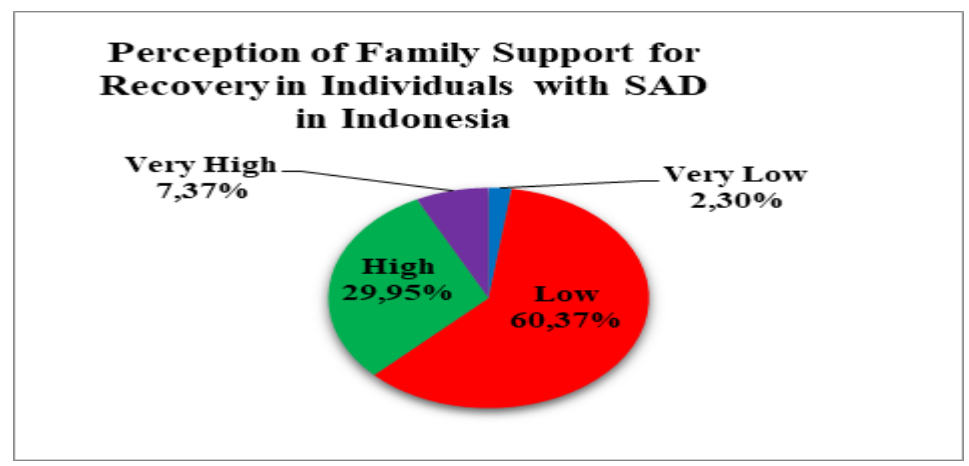

Figure 1. Perceived Level of Family Support for Recovery from SUD

The surprising result was that most families supported themselves in drug rehabilitation programs on individuals with SUD's cognitive or mental aspects. The study results prove that $45 \%$ of the cognitive dimensions of individuals perceive that families support themselves in the rehabilitation program in the high category, and $8 \%$ of individuals in the very high class. Meanwhile, $46 \%$ of individuals in the cognitive dimension feel that their family is low in providing support for SUD recovery, and $1 \%$ has a lower degree. Detailed data can be seen in Figure 2.

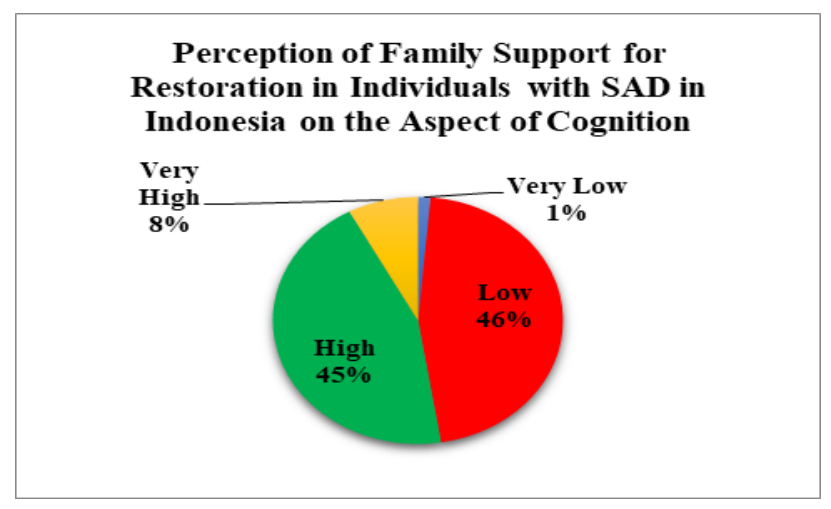

Figure 2. Percentage of Family Support for SUD Recovery from Cognition Aspects

There is a significant difference between the affective dimension and the cognitive dimension regarding the perception of family support for recovery from SUD. The affective dimension focuses on personal feelings about family support. The analysis results show that the majority or $74 \%$ of individuals with SUD feel that their families lack supporting individuals in drug rehabilitation programs, and $11 \%$ of individuals are in the 
poor category. Meanwhile, only $14 \%$ of individuals have high scores, and $1 \%$ of individuals have very high personal feelings related to family support to recover from SUD. Detailed data can be seen in Figure 3.

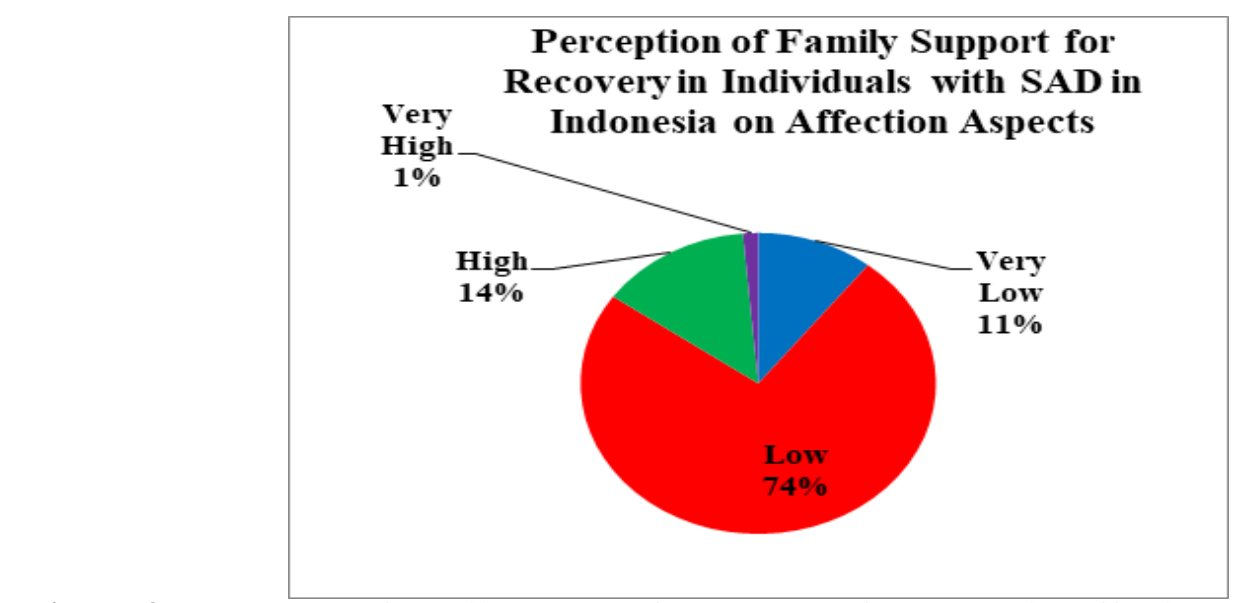

Figure 3. Percentage of Family Support for Recovery from SUD in Affection Aspect

\section{Discussion}

The analysis of family support's perception is shown from two aspects: the cognitive dimension and the affective dimension. The mental and affective dimensions tend to recover from drug addiction. Cognitive and affective measures are measured; There are four forms of family support: emotional support, reward support, information support, and trusted support (Canavan et al., 2000). Perceptions are categorized into two: they can be innate and can go through the learning process (Harnad, 2003). Perception is a theoretical computation of neural sensory processing, which explains how the probabilistic integration of previous expectations and sensory input is (de Lange et al., 2018).

Perceptions of family support from all cognitive and affective aspects are in the medium category. This small category raises individuals with SUD that most families do not support themselves in the drug rehabilitation process. This condition increases the psychological dynamics of individuals with SUD. The relationship between perceptions and family support in this study is based on the stigma that must be integrated into recovery efforts and the intervention process in individuals with SUD (Keyes et al., 2010). Conceptually, affection involves feelings and emotions when confronted with certain stimuli (Gray et al., 2007).

The second result found that on average individuals with SUD have thoughts that their families support their healing efforts. Motivation from the family becomes a supporting element to join the drug rehabilitation program. Motivation to participate in the rehabilitation program is in family support, communities around the rehabilitation environment, and addiction counsellors in the rehabilitation program (Yuly Budi, 2017).

In contrast to the affective aspect of individual perceptions, SUD has a low average. Families do not support individual feelings with SUD. Personal feelings about family support create uncomfortable psychological conditions. This fact is different from the research results that should state that peers and family take part in self-esteem, one of which is drug users' self-esteem (Chii et al., 2017).

There are differences in findings between cognitive and affective aspects because of the mismatch of thinking and reality that raises personal feelings about family support 
to recover from SUD. Differences in thought and reality have a social impact on individuals with SUD. Emotional ties and misconceptions cause the differences between affective and cognitive aspects of family support. This study's personal connections tended to be negative with love-oriented disciplinary control leading to recurrence of children's behaviour. The family method used by the family has different implications for the emergence of undetermined power to control behaviour (Eliza, 2018). Concrete support from the family is in the form of offering or providing someone's needs to overcome problems (Rahmi, 2019), because family support affects the individual psychologically (Prihatsanti, 2014). The main concept is that the family is the first environment. Children get initial experiences that affect their lives and form a cheerful child's personality that can build emotional intelligence and spiritual intelligence (Kartono, 2005).

Misunderstanding of family support can also occur in individuals with SUD. Optimization of the rehabilitation program's counselling process by using all drug users who undergo drug rehabilitation from the rehabilitation group. The use of counselling services in a rehabilitation program can increase emotional control and the chances of recovery. Counselling services based on social and emotional learning can be implemented (Farozin \& Kurniawan, 2019). The imbalance between the high category in the cognitive aspect and the low category on the affective element is because the family does not work in a psychotic condition, reducing relationships in problem-solving and reducing relapses in drug users (Kuipers et al., 2010). In these conditions there needs to be intervention from addiction counsellors and responses through cognitive-behavioural models to prevent relapse (Gustafson et al., 2011).

The addiction counsellor profession in America is recognized as an inclusive profession with the practice of substance user counselling services, certification licenses, and credentials in the implementation of counselling (Miller et al., 2010; Morgen et al., 2012). The profession of an addiction counsellor in Indonesia is regulated in the Regulation of the Minister of Administrative Reform and Bureaucratic Reform of the Republic of Indonesia Number 45 of 2018 concerning Addiction Counsellors' Profession. Addiction counsellors have competence in the use of appropriate and relevant assessments before determining the counselling approach (Supriyanto, 2017). Various counselling services and techniques consisting of individual counselling, group counselling and family counselling, and cognitive and behavioural therapy are implemented to increase knowledge and experience as support for a healthy life (Kusuma, 2020). Counselling approaches and techniques are interventions by addiction counsellors as an alternative to substance addiction recovery through the social dimension.

The discussion related to the findings of cognitive and affective aspects shows the tendency for drug rehabilitation effectiveness through individual counselling and the need for counsellors' intervention through family counselling to increase the rehabilitation program's efficiency. The rehabilitation program's indicators are a decrease in drugrelated deaths, a decrease in users' fewer relapse due to drug tariffs/recidivism, and a reduction in drug sales. The addict remains conscious (recurrence rate decreases), and returns to a productive functioning life (De Costa, 2019).

Low perceptions of family support also pose problems for individuals with SUD and addiction counsellors. Intervention to foster family motivation and trust becomes a mutual urgency. Behavioural disorder intervention with family counselling services is a strategy and assistance by counsellors to increase closeness between individuals and families (Henggeler \& Sheidow, 2012). Family counselling services can help individuals recover from drug addiction. The counselling approach in the rehabilitation program must be able to develop an individual recovery process with SUD. A religion-based 
rehabilitation program as an alternative to personal recovery from SUD (Lyons et al., 2010) for developing a religious mentality (Supriyanto, 2016).

Many interventions are used in addition to interventions with family counselling services. All alternative counselling services are needed in an effective drug rehabilitation program. The answer can be the application of counselling services to social rehabilitation programs. Perceptions of family support can be grown through social interventions and the counselling service process. Interventions affect awareness and acceptance, which results in better treatment and reduced drug use (Luoma et al., 2012). Counselling services in the rehabilitation program aim to make individuals with SUD be accepted by the environment, recover from addiction, and do not return to substance use or do not relapse/relapse. The overall goal of a drug rehabilitation program is scientifically oriented, individualistic, planned, treatment, and a comprehensive relationship to help each other by improving the quality of the rehabilitation program as a program centre and taking action to reduce the relapse rate as a starting point and foothold (Jia et al., 2019). even though drug abuse victims are difficult for society to accept (Bakri \& Barmawbi, 2017).

Counselling services as an intervention must also pay attention to quality. The quality of counselling services in the rehabilitation program is concerned with one aspect of medical, social, religious, and career planning. The conditions of the rehabilitation program form a comprehensive counselling service. The quality of counselling services as an effective intervention can increase personal empowerment and match the needs of individuals with SUD (Ungar et al., 2013). The quality of counselling services also pays attention to the recovery process from substance use. The goal of recovery is so that individuals no longer use the essence and do not relapse. Early pre-recovery, initiation of recovery, maintenance of long-term recovery, and quality of personal / family life in long-term improvement in individuals with SUD require special attention (Canavan et al., 2000 ) with the counselling services of the addiction counsellor profession.

The recovery process takes into account several factors that arise later in the individual. The seven rehabilitation care elements pay attention to the emergence of maladaptive behaviour, social problems that may occur, criminal justice problems, loss of autonomy, problems of intimacy, family problems, and individual fear. One of the most interesting studies can induce recurrence effects in individual substance users, namely fear. Fear arises from thoughts and feelings about post-rehabilitation conditions. Five factors of post-rehabilitation concern are failure of care, the uncertainty of the future, problems of people, problems of the future, and family problems (Chung \& Shek, 2018). The rehabilitation program provides quality treatment, and the agency's agenda is involved in reducing racial inequality in the recovery of substance abuse (Kerrison, 2018) by professional addiction counsellors.

The affective dimension becomes urgent in the discussion and results of research on the perception of family support for healing SUD. Addiction counsellors need to pay attention to the social conditions of individuals with SUD in the family environment, the surrounding community, and the peer environment. This information comes from interviews with the family or the individual himself. Recovery from addiction needs attention to identify changes in social healing because healing occurs through social learning processes and social control that is socially mediated and transmitted in social networks through processes of social influence (Best et al., 2016).

In addition to discussing the intervention process through counselling services, managerial rehabilitation programs also need to be addressed. The paradigm of recovery through a drug rehabilitation program using a management system (El-Guebaly, 2012). Management of the drug rehabilitation program itself is due to government or state 
policies, one of which is Indonesia's. The process of natural recovery from substance use disorders through procedures in each country (Klingemann et al., 2010) needs to be discussed, and recommendations for counselling services through drug rehabilitation should emerge. Counselling services in the rehabilitation program are the government's efforts to address drug abuse (Bachtiar, 2018). In addition to counselling, medical drug rehabilitation needs to be integrated into counselling services (Han, 2018) because rehabilitation helps drug addicts from addiction (Han, 2018) because rehabilitation helps drug addicts from addiction (Lysa Angrayni \& Yusliati, 2018). Comprehensively, the narcotics rehabilitation program is a series of coordinated and integrated efforts consisting of medical struggles, mental guidance, psychosocial, religion, education and vocational training to increase adaptability, independence and self-help, and achieve functional skills after sharing their potential, both physical, mental, social and economic (Timoera \& Martono, 2016).

Indonesia has implemented a community-based drug rehabilitation program. Community-based narcotics rehabilitation programs allow the National Narcotics Agency in every region or centre in Indonesia to overcome drug problems. Coordination and cooperation are potential means to improve the recovery process in the future. The recovery results are necessary instruments (Dodge et al., 2010) to develop self-control and social capacity (Sugiarto, 2018). The collaboration between the National Narcotics Agency and universities, the National Police, the TNI, the Social Service, Islamic Boarding Schools, Hospitals, and the Law on Justice is an instrument in implementing the rehabilitation program. Strong collaboration to prevent other individuals from using the substance. This discussion is also in line with the research results that rehabilitation institutions need to partner with one or more community-based organizations to provide integrated substance abuse, HIV and hepatitis prevention programs for populations in surrounding communities for post-rehabilitation individuals (Rockville, 2010). Collaboration between the National Narcotics Agency and universities from the Guidance and Counseling Department / Study Program strengthens addiction counsellors' profession and quality counselling services. Addiction counselling has a positive impact in preventing relapse, optimism, positive attitudes, staying away from negative environments, family support, planning activities, and choosing good friends (Beni \& Aryanie, 2019).

\section{CONCLUSION}

Perception of family support is a significant predictor of the recovery process for individuals with SUD in drug rehabilitation programs. Individual perceptions are shown from the cognitive and affective dimensions. On the other hand, family support has a cognitive dimension and an affective dimension in individuals with SUD in emotional support, appreciation support, information support, and trusted support. The category of individual perceptions about family support in the SUD recovery process is at a low level. Cognitive aspects or personal thoughts about family support are in the high category, whereas affection or individual feelings about family support in small groups. The difference in cognitive and affective dimensions is due to the mismatch between thinking and reality that raises personal beliefs about family support to recover from SUD. The addiction counsellor can determine and implement counselling services for individuals with SUD with an increased perception that the family is supportive of recovering from drug addiction. Group, individual, and family counselling services are alternatives for developing the perception that the family has provided support to recover from substance addiction.

\section{ACKNOWLEDGMENTS}


We thank the Ahmad Dahlan University Institute for Research and Community Service for providing funding to researchers. A big thank you to the Lido Bogor Drug Rehabilitation Center and staff who have found these facts, as well as to fellow researchers and all parties who have provided input for the smooth writing of this manuscript, from research to writing to publication. Hopefully, this article can be useful and add insight to readers regarding rehabilitation programs, drug prevention, and the addiction counsellor's development from guidance and counselling graduates.

\section{REFERENCES}

Ali, M. M., Dean Jr, D., Lipari, R., Dowd, W. N., Aldridge, A. P., \& Novak, S. P. (2015). The mental health consequences of nonmedical prescription drug use among adolescents. J Ment Health Policy Econ, 18(1), 3-15.

BACHTIAR, I. (2018). REHABILITASI BAGI PECANDU NARKOBA DI YAYASAN ANNUR BALAI PENGOBATAN/WISMA REHABILITASI KH SUPONO MUSTAJAB KABUPATEN PURBALINGGA [PhD Thesis]. IAIN.

Bakri, N., \& Barmawi, B. (2017). Efektifitas Rehabilitasi Pecandu Narkotika Melalui Terapi Islami di Badan Narkotika Nasional (BNN) Banda Aceh. Psikoislamedia: Jurnal Psikologi, 2(1), 86-95.

Beni, H., \& Aryanie, D. (2019). Dampak Konseling Adiksi terhadap Klien Pasca Rehabilitasi Narkoba di Yayasan Pradita Madani Cempaka Kec. Kedawung Kab. Cirebon. Prophetic: Professional, Empathy and Islamic Counseling Journal, 2(2), 243-254.

Best, D., Beckwith, M., Haslam, C., Alexander Haslam, S., Jetten, J., Mawson, E., \& Lubman, D. I. (2016). Overcoming alcohol and other drug addiction as a process of social identity transition: The social identity model of recovery (SIMOR). Addiction Research \& Theory, 24(2), 111-123.

Canavan, J., Dolan, P., \& Pinkerton, J. (2000). Family support: Direction from diversity. Jessica Kingsley Publishers.

Chii, C. Y., Seok, C. B., \& Sombuling, A. (2017). PRECEIVED SOCIAL SUPPORT AND GLOBAL SELF-WORTH IN ADOLESCENCE. JURNAL PSIKOLOGI MALAYSIA, 31(1).

Chung, Y. Y., \& Shek, D. T. (2018). Treatment fears: Barriers to young psychotropic substance abusers receiving residential drug rehabilitation treatment. International Journal of Mental Health and Addiction, 16(6), 1322-1342.

Claro, H. G., Oliveira, M. A. F. de, Titus, J. C., Fernandes, I. F. de A. L., Pinho, P. H., \& Tarifa, R. R. (2015). Drug use, mental health and problems related to crime and violence: Cross-sectional study. Revista Latino-Americana de Enfermagem, 23(6), $1173-1180$.

Cullen, F. T., \& Jonson, C. L. (2011). Rehabilitation and treatment programs. Crime and Public Policy, 293-344.

De Costa, A. S. (2019). Drug Rehabilitation: Is it effective in decreasing the drug epidemic on Long Island, New York.

de Lange, F. P., Heilbron, M., \& Kok, P. (2018). How do expectations shape perception? Trends in Cognitive Sciences, 22(9), 764-779.

Dodge, K., Krantz, B., \& Kenny, P. J. (2010). How can we begin to measure recovery? Substance Abuse Treatment, Prevention, and Policy, 5(1), 31. 
El-Guebaly, N. (2012). The meanings of recovery from addiction: Evolution and promises. Journal of Addiction Medicine, 6(1), 1-9.

Eliza, D. N. (2018). Social Control of the Family on Juvenile Post-Drug Rehabilitation Relapse Behavior. MASYARAKAT: Jurnal Sosiologi, 101-122.

Enoch, M.-A. (2011). The role of early life stress as a predictor for alcohol and drug dependence. Psychopharmacology, 214(1), 17-31.

Farozin, M., \& Kurniawan, L. (2019). Developing Learning Guidance and Counseling Program Based on Social and Emotional Learning in Senior High School. Jurnal Kajian Bimbingan Dan Konseling, 4(2), 47-52.

Fernández-Serrano, M. J., Lozano, Ó., Pérez-García, M., \& Verdejo-García, A. (2010). Impact of severity of drug use on discrete emotions recognition in polysubstance abusers. Drug and Alcohol Dependence, 109(1-3), 57-64.

Gideon, L. (2010). Drug offenders' perceptions of motivation: The role of motivation in rehabilitation and reintegration. International Journal of Offender Therapy and Comparative Criminology, 54(4), 597-610.

Gossop, M. (2013). Living with drugs. Ashgate Publishing, Ltd.

Gray, H. M., Gray, K., \& Wegner, D. M. (2007). Dimensions of mind perception. Science, 315(5812), 619-619.

Griffin, K. W., \& Botvin, G. J. (2010). Evidence-based interventions for preventing substance use disorders in adolescents. Child and Adolescent Psychiatric Clinics, 19(3), 505-526.

Gustafson, D. H., Shaw, B. R., Isham, A., Baker, T., Boyle, M. G., \& Levy, M. (2011). Explicating an evidence-based, theoretically informed, mobile technology-based system to improve outcomes for people in recovery for alcohol dependence. Substance Use \& Misuse, 46(1), 96-111.

Han, B. A. O. (2018). Medicalization of Drug Rehabilitation and Future of the China's Drug Rehabilitation System. Journal of Henan Police College, 1, 5.

Harnad, S. (2003). Categorical perception.

Henggeler, S. W., \& Sheidow, A. J. (2012). Empirically supported family-based treatments for conduct disorder and delinquency in adolescents. Journal of Marital and Family Therapy, 38(1), 30-58.

Hughes, C. E., \& Stevens, A. (2010). What can we learn from the Portuguese decriminalization of illicit drugs? The British Journal of Criminology, 50(6), 9991022 .

Jia, D., Jiang, Z., Zhang, Y., Wang, J., Zhou, Y., Ma, L., \& Guo, S. (2019). The Development Trends in Drug Rehabilitation in China's Judicial Administration Department. Beijing Law Review, 10(1), 239-245.

Kartono, M. (2005). Perbandingan perilaku agresif antara remaja yang berasal dari keluarga bercerai dengan keluarga utuh. Jurnal Psikologi Vol, 3(1), 1.

Kencana, A. S. (2016). Implementasi Kebijakan Pencegahan Pemberantasan Penyalahgunaan dan Peredaran Gelap Narkoba (P4GN) Pada Bidang Rehabilitasi Badan Narkotika Nasional Kota Surabaya [PhD Thesis]. Universitas Airlangga. 
Kerrison, E. M. (2018). Exploring how prison-based drug rehabilitation programming shapes racial disparities in substance use disorder recovery. Social Science \& Medicine, 199, 140-147.

Keyes, K. M., Hatzenbuehler, M. L., McLaughlin, K. A., Link, B., Olfson, M., Grant, B. F., \& Hasin, D. (2010). Stigma and treatment for alcohol disorders in the United States. American Journal of Epidemiology, 172(12), 1364-1372.

Klingemann, H., Sobell, M. B., \& Sobell, L. C. (2010). Continuities and changes in selfchange research. Addiction, 105(9), 1510-1518.

Kuipers, E., Onwumere, J., \& Bebbington, P. (2010). Cognitive model of caregiving in psychosis. The British Journal of Psychiatry, 196(4), 259-265.

Kusuma, R. H. (2020). Penerapan Konseling Adiksi Narkoba di Balai Rehabilitasi Badan Narkotika Nasional (BNN) Tanah Merah Samarinda. Islamic Counseling: Jurnal Bimbingan Konseling Islam, 4(1), 1-16.

Lancaster, K., Duke, K., \& Ritter, A. (2015). Producing the 'problem of drugs': A cross national-comparison of 'recovery'discourse in two Australian and British reports. International Journal of Drug Policy, 26(7), 617-625.

Luoma, J. B., Kohlenberg, B. S., Hayes, S. C., \& Fletcher, L. (2012). Slow and steady wins the race: A randomized clinical trial of acceptance and commitment therapy targeting shame in substance use disorders. Journal of Consulting and Clinical Psychology, 80(1), 43.

Lyons, G. C., Deane, F. P., \& Kelly, P. J. (2010). Forgiveness and purpose in life as spiritual mechanisms of recovery from substance use disorders. Addiction Research \& Theory, 18(5), 528-543.

Lysa Angrayni, S. H., \& Yusliati, H. (2018). Efektivitas Rehabilitasi Pecandu Narkotika Serta Pengaruhnya Terhadap Tingkat Kejahatan Di Indonesia. Uwais Inspirasi Indonesia.

Maehira, Y., Chowdhury, E. I., Reza, M., Drahozal, R., Gayen, T. K., Masud, I., Afrin, S., Takamura, N., \& Azim, T. (2013). Factors associated with relapse into drug use among male and female attendees of a three-month drug detoxificationrehabilitation programme in Dhaka, Bangladesh: A prospective cohort study. Harm Reduction Journal, 10(1), 14.

Merrick, M. T., Ports, K. A., Ford, D. C., Afifi, T. O., Gershoff, E. T., \& Grogan-Kaylor, A. (2017). Unpacking the impact of adverse childhood experiences on adult mental health. Child Abuse \& Neglect, 69, 10-19.

Miller, G., Scarborough, J., Clark, C., Leonard, J. C., \& Keziah, T. B. (2010). The need for national credentialing standards for addiction counselors. Journal of Addictions \& Offender Counseling, 30(2), 50-58.

Morgen, K., Miller, G., \& Stretch, L. S. (2012). Addiction counseling licensure issues for licensed professional counselors. The Professional Counselor, 2(1), 58-65.

Petrova, H. A., Zavarzina, O. O., Kytianova, I. P., \& Kozyakov, R. V. (2015). Social and personal factors of stable remission for people with drug addictions. Psychology in Russia, 8(4), 126.

Prihatsanti, U. (2014). Dukungan keluarga dan modal psikologis mahasiswa. Jurnal Psikologi Undip, 13(2), 196-201. 
Rahmi, Z. (2019). Identifikasi Dukungan Keluarga Dalam Membimbing Pasien Rehabilitasi Napza Pada Rumoh Harapan Aceh Kota Banda Aceh,(Jurusan Bimbingan dan Konseling Islam [PhD Thesis]. UIN Ar-Raniry Banda Aceh.

Rockville, M. D. (2010). Substance Abuse and Mental Health Services Administration Center for Substance Abuse Treatment. Center for Substance Abuse Treatment National Advisory Council.

Roth, A. M., Armenta, R. A., Wagner, K. D., Roesch, S. C., Bluthenthal, R. N., CuevasMota, J., \& Garfein, R. S. (2015). Patterns of drug use, risky behavior, and health status among persons who inject drugs living in San Diego, California: A latent class analysis. Substance Use \& Misuse, 50(2), 205-214.

Sari, D. M. (2017). GAMBARAN PROGRAM DISEMINASI INFORMASI P4GN OLEH BNN KOTA SURABAYA. JURNAL PENELITIAN KESEHATAN, 15(2), 82-91.

Stone, A. L., Becker, L. G., Huber, A. M., \& Catalano, R. F. (2012). Review of risk and protective factors of substance use and problem use in emerging adulthood. Addictive Behaviors, 37(7), 747-775.

Sugiarto, D. L. (2018). Pusat Rehabilitasi Narkoba Sumatera Selatan [PhD Thesis]. Universitas Katolik Musi Charitas.

Supriyanto, A. (2016). Islamic Guidance for Drug Addiction. Jurnal Konseling Dan Pendidikan, 4(2), 98-104.

Supriyanto, A. (2017). Rehabilitation counseling: Concept assessment guidance and counseling for drugs abuse. Prosiding Seminar Bimbingan Dan Konseling, 1(1), $19-30$.

Supriyanto, A., \& Hendiani, N. (2018). Aspect, validity, and reliability family support perception scale for substance abuse disorders. Counsellia: Jurnal Bimbingan Dan Konseling, 8(1), 7-18.

Timoera, D. A., \& Martono, A. (2016). Efektivitas rehabilitasi dan pola pembinaan terhadap pecandu narkotika di balai besar rehabilitasi badan narkotika nasional Indonesia Lido Bogor. Jurnal Ilmiah Mimbar Demokrasi, 16(1), 81-102.

Ungar, M., Liebenberg, L., Dudding, P., Armstrong, M., \& Van de Vijver, F. J. (2013). Patterns of service use, individual and contextual risk factors, and resilience among adolescents using multiple psychosocial services. Child Abuse \& Neglect, 37(2-3), $150-159$.

Vakonaki, E., Tzatzarakis, M., Tsiminikaki, K., Nathena, D., Fragkiadaki, P., Kalliantasi, K., Kanaki, K., Vaki, G., Plaitis, S., \& Tsoukalas, D. (2019). Effect of chronic and heavy drug abuse on biological aging. World Academy of Sciences Journal, 1(2), $67-73$.

Wulandari, T. (2016). Implementasi Kebijakan Pencegahan Dan Pemberantasan Penyalahgunaan dan Peredaran Gelap Narkoba (P4GN) Pada Kalangan Pelajar Di BNNP DIY. Spektrum Analisis Kebijakan Pendidikan, 5(5), 466-477.

YULY BUDI P, E. (2017). MOTIVASI REMAJA DALAM MENGIKUTI REHABILITASI NARKOBA DI YAYASAN PLATO FOUNDATION PROVINSI JAWA TIMUR. Kajian Moral Dan Kewarganegaraan, 5(02). 